\title{
Profitability in Swedish Micro Firms: A Quantile Regression Approach
}

\author{
A. Khalik Salman ${ }^{1} \&$ Darush Yazdanfar ${ }^{1}$ \\ ${ }^{1}$ Department of Social Sciences, Mid Sweden University, Östersund, Sweden \\ Correspondence: A. Khalik Salman, Department of Social Sciences, Mid Sweden University, SE-831 25 \\ Östersund, Sweden. Tel: 46-0-63-165-794. E-mail: khalik.salman@miun.se
}

\author{
Received: February 14, $2012 \quad$ Accepted: May 10, $2012 \quad$ Online Published: July 1, 2012 \\ doi:10.5539/ibr.v5n8p94 \\ URL: http://dx.doi.org/10.5539/ibr.v5n8p94
}

\begin{abstract}
The purpose of this study is to identify a function for the profitability of Swedish micro firms in the sectors of health, transport, trade and metal. In order to understand how micro firms relate to key variables, such as firm size, growth of sales, productivities, lagged profits, asset turnover and firm's age, OLS (Ordinary Least Squares), and the more robust quantile regression techniques, are used to estimate micro-firm profitability. Data from 2007 is used for this purpose. The results show that growth (competitive condition) and total factor productivity (comparative advantage) have a significant positive effect on micro-firm profitability, and that size (diminishing returns states) is found to have a rather significant negative effect on micro-firm profitability. The results also indicate a strong relationship between microeconomic theory suggestions and micro-firm profitability for the all micro firms except those in the metal sector. Moreover, the quantile regression approach provided a better understanding, regarding the dynamics of the factors that affect profitability, and provided more interesting results than OLS normally do.
\end{abstract}

Keywords: estimating micro-firm profitability, microeconomics suggestions, quantile regression approach

\section{Introduction}

The interest to study the determinants of profitability has grown over time in a wide rage of scientific disciplines. Internal resources of a company are believed to have significant impact on profitability by strategic management, finance and accountancy scholars (Barney, 2001; Stulz, 1990). Slater \& Olson (2002) recognise the competition within the market in which the company operates in as the determining factor of profitability in Industrial economics. Previous empirical studies have emphasised the medium-sized and large firm profitability determinants, however they have neglected the determinants of micro-firm's profitability. Micro businesses play a key role in the generation of jobs, new ideas and encouragement of entrepreneurial activity, and make a major contribution to the well-being of nations. The profitability or performance of micro firms is thus important for the evolution of firms' and regional development.

A company' ability to increase profitability, to survive or expand is more an issue these days due to the existance of the free market. Countries utilise investment liberation policies and this has resulted in the increase in national and international competition. Micro firms in Sweden contribute to the economic and employment growth in a great extent; however there is a lack of empirical studies on the profitability of these firms. This paper aims to address this limitation in the study and explore the factors that lead to small firm's profitability (Note 1).

Size, market power, debt and liquidity have been found as the determinants of profitability in the study led by Goddard, Tavakoli and Wilson (2005). However, due to the limitation of the statistical data relating to the firms' market share in our database, the marketing power is not considered as a variable in this study. Following Goddard and his colleagues' (2005) research on the determinants of profitability, the influence of growth, asset turnover, and the total factor productivity are considered as variables having impact on companies' profitability. First, by including firm growth, we intend to test empirically the Greiner (1972) model for the case of the micro firm. Greinre (1972) concludes that the relationship between growth and profitability is complex and somehow contradictory at points. Further on in this research, the role of asset turnover is going to be examined in relation with profitability; thus the companies' profitability will be empirically tested to find out the impact of asset turnover. It is believed that greater amounts of asset turnover will lead to more profitability.

The role of micro firms has attracted the attention of the governments after 1970s due to the belief that micro firms will contribute to the economy and employment opportunities (Note 2). Also, in Sweden, micro firms received 
positive appraisals in the subsequent economic stagnation of the 1990s, and even in the recent financial crisis 2009 . Although the micro-firm policy in Sweden has been in effect since the 1980s, from the perspective of helping the weak overcome economic disadvantages, Sweden's Government revised the micro firm basic law for the first time in the 1980s, which characterised micro firms positively, as sources of the country's economic vitality, and creating employment opportunities. The revised law declared that the Government has the responsibility to offer the necessary support to promote the start-up of new firms.

The main contribution of this paper is its exploration of the profitability determinants of Swedish micro firms for 2007. The relationship of firm size, age, total factor productivity, firm growth, asset turnover and profitability is examined for a large sample of micro firms in Sweden. These firms have between 1 and 9 employees, and operate in the whole of Sweden. The year 2007 covers a time of major changes in the regions' industrial policy and in government policy. Our evaluation is also an attempt to highlight the effects of various regional development policy programmes on the growth and formation of firms. Our results, from a large sample of micro firms, show that the relationship of profitability, size, growth and productivity of firms is highly sensitive to the methods of estimation, functional form and definition of profitability.

Micro firms are excellent samples for studying the profitability function. All firms have the same objective measures of firm profit, and thus it is possible to identify firm performance and profitability life cycles. The current study thus replicates and extends past studies on profitability. Most past studies tended to treat all firms as equal, and ignored variations in characteristics that may be related to their ability to affect organisational profit. It seems reasonable to investigate further the possibility that all firms, or in the case of micro firms, do not have equal ability, and that those with superior ability may be better able to generate improvement in profitability. Most previous studies have used descriptive statistics methods, the generalized methods of moments (GMM), and the ordinary least squares (OLS) techniques to analyse the profitability of micro firms. In this study we will use the OLS and the more robust quantile regression techniques.

We investigate the profitability determinants of the four micro firms for the cross-section of Swedish data, for 2007. The data is collected from Affärs Data, which maintains a comprehensive database of financial and accounting records for all limited liability and listed companies in Sweden, and covers all firms listed in the Swedish Central Register of Enterprises.

Since there are no other papers dealing with micro firm's profitability that apply quantile regression, this study contributes to the literature on micro-econometrics of economics of firm by applying for the first time quantile regression method to examine the impact of firm size, growth, age, productivity and assets turnover on its profitability.

The relationship between growth rate as dependent variable (measured in term number of employees) and the lagged number of employees and dummy variable (as two independents variables) has merely been investigated by Alex Coed. Werner HölzI (2009).

The main purpose of this study is to provide additional empirical evidence to measure the profitability determinants of micro firms, with special reference to Sweden. Specifically, our aim is to identify the relationship between firm's profits and factors, such as the size, age, asset turnover, and firm age, that influence profitability.

For several reasons, firstly, Sweden provides interesting context for this study owing to their position as economies in transition and had joined the position of the more industrial European countries in the period under study. Secondly, it had adopted new policies for development, great support to small and micro firm companies, and more dependence on industry, moving towards increased globalization, and international competition. Hence, an innovative feature of this study is evolution of profitability model during a country's transmissions to new technological status. Thirdly, it also permits estimation of the profitability model become more or less similar over time with respect to change in productivity, quantity sale and number of employees. Accordingly, this study provides useful insights, at the cross-country rank, about change in a major activity, within each of economy.

The remainder of this paper is organised as follows: Section 2, presents a review of some relevant literature. In Section 3, we discuss the methodology used in this paper, while Section 4 presents the results and the important findings. Finally, in Section 5, we give some conclusions and policy recommendations.

\section{Literature Review of the Determinants' Selection}

Methodologically, in order to improve the validity of results, this study implements a different method, analysing more variables than the other studies. In addition, we shift in the research perspective, and use large sample of unlisted micro firms in four industries predominated by service segments instead and thereby extends previous research. Moreover, whereas variables such as assets turnover, total factors productivity have not been regarded as 
the important determinates in micro firm profitability function in existing quantitative studies of productivity and growth in Scandinavian, our study highlights on these key profitability determinants. Further, former Scandinavian studies have not considered the microeconomics suggestions such as the comparative advantage condition and competitive market effects (substitution effect). Additionally, most of the previous international studies measured the size variable by the quantity sale or assets. However, in this study the number of employees have been uses as proxy for size based on the microeconomics theory hypothesis that the law of diminishing returns states that as a firm uses additional of a variable factor of production with a given quantity of the unchanging factor of production, the marginal return of the variable factor eventually diminishes. Microeconomic theory suggests that comparative advantage may be important determinants of the profitability, consequently, the previous studies have not even consider the comparative advantage variable as a determinant for the micro firms profitability models.

The study focuses on a broad set of Swedish micro firms, in the trade, transport, health and metal sectors. For the classification of micro firms by size we use the definition applied by the European community (Europstat, 1994), where micro firms have 1-9 employees. Next, we present the possible relationship between explanatory variables and the profitability of Swedish micro firms.

\subsection{Lagged Dependent Variable (Profitability)}

The competition in the markets has got a role in determining company's profitability. Regardless of the divergence that exists in the market, the companies retain their profitability over time by the market dynamics. As some companies leave the market, the new ones start operating (Mueller, 1986). The higher persistence of profitability is more prevalent in the larger companies due to their greater flexibility to the changes in the market comparing to the smaller firms (Dilling-Hansen, 2005).

The company's characteristics as well as the market specifications are recognised as determining the profitability of a company and the lagged profitability is used as a proxy variable for the persistence of profitability (Hawawini et al., 2003; Schumacher \& Boland, 2005). Previous profit such as retained earnings, product and process innovation also help the company to invest and develop; the more the previous achievements, the stronger the company in retaining its competitive advantage. The role of lag dependency of profits has been emphasised by Geroski and Jaquemin (1998) as well.

\subsection{Growth}

The growth of the quantity sale is independent variable in this study to reflect the national and international competition and the Swedish micro firm access to the markets. Our measure of firm growth is measured by the percentage change in quantity sale. In keeping with former studies, we define firm growth as the Logarithm difference of quantity of sale: $\left(\mathrm{GR}=\mathrm{Qs}_{1}-\mathrm{QS}_{0} \mathrm{x} 100\right)$.

\subsection{Firm Size}

In order to measure the firm size, conventionally the total number of employees, sales and the amount of poperty are the factors that are measured. The recent research has focused more on the number of employees as the measurement of the size. The size is mainly investigated due to the interest to find out the relationship between employment and size. That is why; we have also adopted the number of employees as a measure of size in the Swedish case, because the government began to show an interest in the role of micro firms from the viewpoint of maintaining economic power, and creating employment opportunity. Meanwhile, we thought that the number of employees variable can control for various factors characterising the sample firm, its performance, human capital and the labour market conditions as well.

The company size has a critical role in determining profitability (Dilling-Hansen, 2005; Gschwandtner, 2005; Hardwick, 1997; Winter, 1994; Wyn, 1998). Persistence of profitability is greater in larger companies, because compered with smaller companies, the larger ones have more access to resources and consequently they have more flexibility to the changes in a dynamic market. In contrast, having based their arguments on agency theory, some believe that company size has a negative relationship with the profitability, due to the increasing clashes and dissention between the shareholders and the managers, these conflicts will lead to lack of control (Pi \& Timme, 1993). Jensen and Murphy (1990) discuss that larger firms enhance the managers' salary and job security; however, this will result in the managers' having less focus on improving the company's financial gains. This negative relationship between the company size and profitability has been also found in Harhoff et al. (1998) study on the manufacturing, service, trade and construction industries.

The fact that the number of employees has been regarded as proxy for size is based on the microeconomics theory hypothesis that the diminishing returns. The theory explains that as a firm uses additional of a changeable factor of 
production (worker) with a same quantity of the fixed factor of production, the marginal return of the variable factor eventually diminishes.

\subsection{Firm Age}

Firm's age has been found as an explanatory variable for profitability in the empirical research. According to Evans (1987), age and profitability are positively related, and the growth of a younger firm is faster than that of an older one. Glancey (1998) has relayed the profitability to the firm age as well; however, he claims that dynamic economies of scale and experience are drivers for profitability in older firms. Reputation is also believed to be influential for gaining higher margins and profitability. In contrast, some have observed a negative relationship between age and profitability due to consolidation of behaviours that have been developed overtime and not easily amenable to change. This study has also found that the effect of firm age on firm profitability is significantly negative.

\subsection{Total Factor Productivity Growth}

Demsetz (1973) introduces the superior firm hypothesis in which the level of efficiency distinguishes the firms from each other. The higher productivity gains a competitive edge for a company over the less productive competitors and leads to profitability. It is believed that firms' profitability is higher when they have got higher degrees of total factor productivity. Jovanovic (1982) extends this argument when he emphasise that the firms with lower levels of productivity exit the market and the ones with higher levels of efficiency will survive in the market.

The firms have higher levels of profitability when the productivity is greater and more persistent. This finding lens supports the firm hypothesis in Demestz (1973). High levels of total factor productivity cause high firm profitability. A potential explanation is that high productivity, manifested in, for example, low average production costs, higher product quality or higher output quantities, with fewer inputs, and lead to high profit.

Consequently microeconomics theory implies that comparative advantage of Swedish companies' production may be important determinants of the profitability. However, the previous studies have not even considered the comparative advantage of production variable as a determinant for the Scandinavian micro firm profitability or growth models. This factor reflects the opportunity cost of production in relative terms for Swedish companies with Scandinavian companies and technological progress as well. Accordingly, since firms from a developed country should have a comparative advantage in innovation and advanced products made by highly skilled worker using superior technology, a positive sign of productivity is expected. Based on the fact that economies of scale and the fixed costs related to productivity, it can be expected that a positive influence of firm total factor productivity on the profitability.

\subsection{Asset Turnover}

The sales revenue generated by each unit of asset is called asset turnover, which is a critical measurement for evaluating the efficiency of the firm. This can be calculated turnover when the sales revenue, is divided by the total net assets. Changes in the firm's productivity might lead to changes in asset turnover that reflects changes in the firm's current profitability. As a result, asset turnover and its variations will predict the possible future fluctuations in the firm's profitability. The sign of the coefficient for the asset turnover founded in our study is significantly positive. This implies that the higher the level of asset turnover, the more profitable the micro firms. We also find that asset turnover correlates positively with the dependent variable, profitability. Asset turnover measurement is the quantity sales divided by total assets multiplied by 100 . We regress the percentage ration.

\section{Methodology}

\subsection{Model Specification}

In this section, we present the specification of the model we used in our analysis, together with the estimation methodology. The main task is to distinguish the effect of the different independent variables on the profitability of the micro firms. The basic empirical model is as follows:

$$
\mathrm{Y}_{\mathrm{t}}=\alpha+B_{1} \operatorname{LnX}_{\mathrm{t}-1}+B_{2} \operatorname{LnX}_{\mathrm{t} 2}+B_{3} \mathrm{LnX}_{\mathrm{t} 3}+B_{4} \mathrm{Y}_{\mathrm{t}-1}+B_{5} \operatorname{Ln} \mathrm{X}_{5}+B_{6} \mathrm{X}_{6}+\varepsilon_{\mathrm{t}} \quad \mathrm{t}=1,2, \ldots . \mathrm{T}
$$

$\mathrm{Y}=$ the profitability (the ratio of operational results to total assets \%)

$\mathrm{X}_{1}=$ growth rate of sales (measured by the growth of quantity sales to reflect competitive condition)

$\mathrm{X}_{2}=$ size (logarithm of the number of employees to present the law of diminishing returns)

$\mathrm{X}_{3}=$ total factor productivity growth (measured the comparative advantage of production or opportunity cost of producing a good. This represents also the opportunity cost of production in relative terms for Scandinavian and Swedish micro firms. 
$\mathrm{Y}_{\mathrm{t}-1}=$ lagged dependent variable profitability (proxy variable to capture the unobserved variables such as the exchange rate)

$\mathrm{X}_{5}=$ asset turnover (the ration of quantity sales to total assets \%)

$\mathrm{X}_{6}=$ age

$\varepsilon_{\mathrm{t}}=$ error terms assumed to be: $\varepsilon_{\mathrm{t}} \sim \mathrm{N}\left(0, \sigma^{2}\right)$.

$\mathrm{Ln}=$ the natural logarithm

$\mathrm{t}-1=$ lagged period

$\alpha=$ an intercept, and $B_{1}, B_{2}, B_{3}, B_{4}, \mathrm{~B}_{5}$, and $B_{6}$ are parameters associated with the respective independent variables included in the model. $T$ is the total number of observations. This model is estimated separately for each of the four categories of Swedish micro firms, namely: Retail trade, Metal, Transport and Health. These four firms were chosen because they were the four foremost firms in Sweden.

\subsection{Estimation Methodology}

In this section, we present the estimation methodology used to study and analyse the profitability of these four categories of micro firms. Previous international studies have either used descriptive statistics or OLS to analyse the profitability of micro firms. In this study, in addition to these methods, we also apply a more robust estimation methodology, such as the quantile regression technique.

We start by estimating our model using the quasi-panel methodology, by applying the OLS method to the data for 2007. The results' estimation is presented in Tables 3, 4 and 6 in Section 4.

However, due to a few reasons, it is preferred to estimate the linear models by utilising quantile regression. Firstly, identifying the average behaviour has been targeted by most econometric techniques. Through a quartile regression, the distribution of the firm's growth and performance can be taken into consideration; thus, this technique can reveal a better account of the relationships between the variables. In this research, profitability and performance are studied in details and applying quantile regression enables us to analyse the relationship between performance and profitability more in details, and helps to investigate how long the jobs created will last and if high performance is the result of high profitability in the firms.

In addition, we know that the standard-squares assumption of a normally distributed error term does not hold for our data, because the profitability variable follows skewed and fat-tailed distribution as demonstrated in Figures 1.
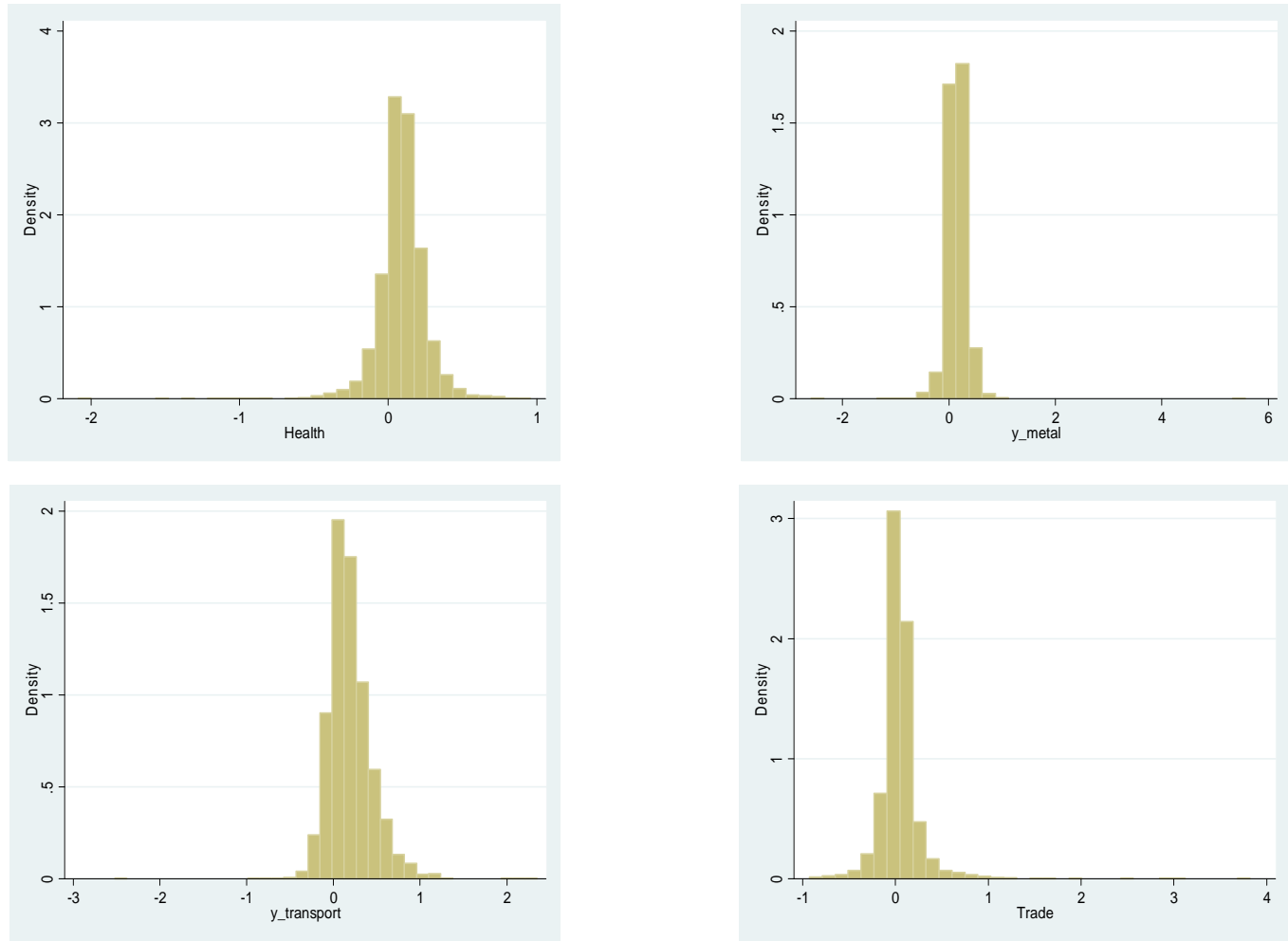

Figure 1. The distribution plots of the four sectors' dependent variables 
Therefore, the use of quantile regression weakens the assumption that the distribution of normality of the error terms that they are identically distribution at all the parts of the conditional distribution. This will provide us with the opportunity to investigate at different points of the conditional distribution of the differences in the relationship between the endogenous and exogenous variables. The partial correlation changes across the quantile will be examined through utilising quantile regression, this will shed some light on how the explanatory variables shape the distribution.

Conditional quantile functions can be estimated by the statistical technique of the quantile regression. Whereas the models for conditional mean functions can be measured by minimising sums of squared residuals through classical linear regression methods. Therefore, models for the conditional median function and the full range of other conditional quantile functions can be estimated through a mechanism offered by quantile regression methods. There is less sensitivity to outliers and departure from the normality assumption when quantile regression rather than linear regression methods are used. Coad and Rao (2008), Fotopoulos and Louri (2004), and Reichstein et al. (2009) have used quantile regression methods in analysing the firm growth.

Koenker and Bassett (1978) originally suggested quantile regression as an alternative method to the OLS. This was introduced as a more robust regression technique that can be applied when there is not a normal distribution in the errors. The conditional quantile is specified as a linear function of covariates through the quantile regression. For the $\theta^{\text {th }}$ quantile, a common way to rewrite model (1) is as follows:

$$
y_{t}=x_{t}^{\prime} \beta_{\theta}+\varepsilon_{\theta t},
$$

where $\beta_{\theta}$ is a vector of regression parameters corresponds to the $\theta^{\text {th }}$ quantile, $x_{t}$ is a vector of explanatory variables, $y_{t}$ is the dependent variable, and $\varepsilon_{\theta t}$ is error term. The $\theta^{\text {th }}$ conditional quantile of $y$ given $x$ is

$$
Q_{\theta}\left(y_{t} \mid x_{t}\right)=x^{\prime}, \beta_{\theta}
$$

At this stage the assumption that $Q_{\theta}\left(\varepsilon_{\theta t} \mid x_{t}\right)=0$ should be satisfied.

For more discussion regarding this methodology and its applications we refer to Hao and Naiman (2007).

The $\theta^{\text {th }}$ quantile regression $(0<\theta<1)$ of $y$ is the solution to the minimisation of the sum of absolute deviation residuals:

$$
\min _{\beta} \frac{1}{n}\left(\sum_{t, y_{i} \geq z_{i}^{\prime} \beta} y_{i}-x_{i}^{\prime} \beta\left|\theta+\sum_{t: x_{x}^{\prime} \beta}\right| y_{i}-x_{i}^{\prime} \beta \mid(1-\theta)\right)
$$

Now, by weighting the residuals differently we can estimate different quantiles or percentiles. In the situation when we let the residuals receive equal weight, we can estimate the median regression. When estimating the $75^{\text {th }}$ percentile, we let the positive residuals to be weighted by 0.75 and the negative residuals by 0.25 , and so on Processing in this manner the quantile regression minimises the weighted absolute values of the residuals and at the same time uses all the available data. However, this cannot be done when applying the OLS.

In our study, we use quantile regression methods to estimate the $25^{\text {th }}$ through to the $75^{\text {th }}$ percentile. In our tables we only present results for the $25^{\text {th }}, 50^{\text {th }}$ and $75^{\text {th }}$ percentiles. Note that the $50 \%$ quantile regression is also called the median regression method, which fits the regression hyper plane that minimises the sum of the absolute residuals rather than the sum of the squared residuals. In this manner, we can get a better insight into the effects of the independent variables on the dependent variable, at different parts of the profitability distribution. The calculations were performed using the statistical program package STATA Version 11.0

\section{Results}

In this section we present the most important results regarding the descriptive statistics, and the estimation results of the OLS and the quantile regression methodologies.

\subsection{Results of the Descriptive Statistics}

Table 1 displays the means, standard deviations, coefficients of variation, skewness and kurtosis for the profitability variable for all micro firms. The coefficient of variation results show that the profitability of the metal firm, from year to year, fluctuates more than the profitability of the other firms. Health shows the most stable results. 
Table 1. Mean, standard deviation, coefficient of variation*, skewness and kurtosis profitability for all micro firms $^{* *}$

\begin{tabular}{lllll}
\hline & Health & Transport & Metal & Trade \\
\hline Mean & .915 & .190 & .145 & .112 \\
St. dev & .163 & .253 & .217 & .110 \\
Variance & .028 & .064 & .064 & .0122 \\
Coefficients of variation \% & 17.860 & 133.280 & 149.078 & 98.293 \\
Skewness & -1.481 & .776 & .776 & 1.230 \\
kurtosis & 19.665 & 10.784 & 10.784 & 6.309 \\
Min & -2.087 & -2.522 & -2.592 & -.099 \\
$\max$ & .958 & 2.350 & 5.573 & .837 \\
\hline
\end{tabular}

Note: ${ }^{*}$ the coefficient of variation expresses the standard deviation as a percentage of the mean. Comparing variation using the standard deviation would be misleading. The coefficient of variation overcomes this problem by adjusting for the scale of units in the population (Newbold, 2003). ${ }^{* *}$ Health number of observations $=3,716$, Transport number of observations $=3,526$, Metal number of observations $=2,210$, Trade number of observations $=3,080$.

Table 2 reports the correlation among all variables of the model for all micro firms, and shows that the asset turnover has a stronger linear relationship $(r=0.63)$ with profitability than the other variables for three of the four firms. The Growth variable comes in second place for these firms except for metal, and also reveals a small positive relationship with profitability for the firms. The exception is the metal firms, for which the growth variable has the lowest positive correlation $(r=0.24)$ with performance. The table also shows that the firm's age is negatively correlated with profitability for all firms.

Table 2. Correlations for all variables

\begin{tabular}{lcccccc}
\hline Profitability & $\mathrm{X} 1$ & $\mathrm{X} 2$ & $\mathrm{X} 3$ & $\mathrm{X} 4$ & $\mathrm{X} 5$ & $\mathrm{X} 6$ \\
\hline Health & .37 & .19 & .15 & .69 & -.04 & -.06 \\
Transport & .25 & .13 & .11 & .63 & .15 & -.13 \\
Metal & .12 & .25 & .11 & .24 & -.10 & .14 \\
Retail Trade & .20 & .10 & .24 & .63 & .06 & -.16 \\
\hline
\end{tabular}

\subsection{Estimation Results}

In general, using both estimation methods, we find variables such as growth, productivity and asset turnover to have a positive and highly significant effect on the profitability of the different firms. The magnitude of the parameters, however, varies for the different firms and estimation methods. The intercept is also positively significant in almost all cases.

In the following, first an OLS model is estimated followed by the quantile regression for each of the different firms (see Tables 4, 6 and 8). For illustrative purposes, the results for the metal micro firm are a commented upon further. The results for the other firms will follow analogously.

\subsection{Ttrade Micro Firms}

The OLS results for these firms show that, in addition to firm growth (our measure of firm growth is the change in quantity of sales), productivity and lagged profitability, during the year of study, have been shown to be significant with positive effects. The firm size (our measure of firm size is the number of employees) has also been shown to be significant at all significance levels ( $p$-value $=0.000$ ), but with a negative effect. Most studies found that there is a negative relationship between firm size and profit, indicating that most service sectors have something like a minimum efficient scale of operation (Johnson, Conway \& Kattuman, 1999). In addition, Table 3 presents the firm's age to be significant and having a negative effect.

When comparing the results of the estimates of the OLS and the quantile regression, we can see that the results from the quantile regression method are more informative with regard to inferences about the effect of the explanatory variables on the dependent variable. For illustrative purposes, and to foster the reader's understanding of quantile regression, the equation for the $25^{\text {th }}$ percentile is illustrated briefly; all the others follow analogously. In order to understanding the functioning of quantile regression, and at the same time also point to the differences from OLS, we focus on the results for the independent variable, which are now shown not to be statistically significant. This can mean that these variables have not shown any significance on the dependent variable, in the 
case when the profitability is low. Moreover, the magnitude of the effect of productivity is also reduced from 0.15 in the OLS case to 0.14 in the 25 th percentile case. For the cases with higher percentiles, the effect of this variable becomes larger in magnitude to achieve the value of 0.22 in the case of the 75 th percentile, i.e. when the profitability is very high.

However, in the case where the firm has a fairly high profitability, all the variables have shown significant effects. The effects of firm growth, productivity, lagged profitability and macroeconomic alteration affect during years are positive. This means that when the profitability of the firm is fairly high these variables can affect the profitability in a positive way. The lagged dependent variable during the time of study has a larger positive than the growth, productivity and assets turnover, and that firm size and age has a larger negative effect than the firm age. The OLS and quantile regression results in all cases showed that the firm age variable has a negative sign and non-significant.

\subsection{Health Micro Firm}

When applying the OLS, in addition to growth, lagged profitability and productivity have also shown a rather significant positive effect. This effect becomes larger and more significant. Moreover, when considering the quantile regression; the results have also shown that size has a negative significant effect and that the effect becomes larger as the profitability becomes higher. Note that this result is not discovered at all by the OLS. And the results have also shown that firm age has a negative effect but not significant.

\subsection{Transport Micro Firm}

The OLS results for these firms show that in addition to the growth and productivity variables, which have positive and significant, asset turnover also has a positive effect that is significant (the $p$-value for the parameter is 0,000 ). This means that the importance of this variable is stronger when considering the results from the 75 th percentile, which stands for the cases of very high performance. We also find size to have a highly significant negative effect on the dependent variable. This effect is more negative for the cases with 50th percentiles (i.e. for mediocre profitability), and the 75 th percentile. This means that the effect of changing the number of employees is more negative when the profitability of the firm is mediocre, and less negative when the firm has very high profitability. The OLS and quantile regression results in all cases showed that the firm's age variable has a negative sign and is non-significant.

\subsection{Metal Micro Firm}

Using the OLS, the variable that has a significant effect are growth, lagged profitability, productivity and asset turnover with an estimated parameter value of $0.023,0.128,0.23$ and 0.054 respectively. Now, by using the quantile regression, we find that the value of these parameters increases with the estimated percentiles, to achieve the values of $0.60,0.11,0.28$ and 0.05 respectively, in the case of the 75 th percentile, i.e. the size coefficient shows a surprising result, when the profitability is very high. In this case, in the 50th and 75th percentiles, the firm size has also been shown to have a negative significant effect, while the firm size variable has shown a non-significant and also negative effect in the case of the OLS. On the other hand, looking at the output of the 25th percentile regression regarding the size variable, one finds a more differentiated picture than in the cases of the 50th and 75th percentiles. The results here would suggest that for this low percentile the effect seems to be even smaller, has a negative sign and is non-significant, which is different from what is suggested by the 50th and 75th percentile regression. Again, such information cannot be found from the OLS regression. In general, when using the quantile regression approach, we go deeper into the dynamics of the factors that affect profitability, and hence obtain more interesting results than the usual OLS can provide. The OLS and quantile regression results, in all cases showed that the firm age variable has a negative sign and is non-significant.

Table 3. The OLS method results for trade

\begin{tabular}{llllllll}
\hline $\mathrm{R}^{2}=0.45$ & Constant & $\mathrm{X} 1$ & $\mathrm{X} 2$ & $\mathrm{X} 3$ & $\mathrm{X} 4$ & $\mathrm{X} 5$ & $\mathrm{X} 6$ \\
\hline Coef. & -.008 & .041 & -.031 & .075 & .149 & .007 & -.001 \\
Std Err & .0162 & .058 & .005 & .012 & .003 & .001 & .0000 \\
P-Value $^{*}$ & 0.615 & 0.000 & 0.0000 & 0.000 & 0.000 & 0.000 & 0.000 \\
\hline
\end{tabular}

Note: Number of obs $=3080, \mathrm{~F}(7,37072)=360.45$, Root MSE $=.0818$, Prob $>\mathrm{F}=0.0000$. 
Table 4. The quantile regression results for trade

\begin{tabular}{|c|c|c|c|c|c|c|c|}
\hline \multicolumn{8}{|l|}{$25 \%$} \\
\hline $\mathrm{R}^{2}=0.3105$ & Constant & $\mathrm{X} 1$ & $\mathrm{X} 2$ & X3 & $\mathrm{X} 4$ & X5 & X6 \\
\hline Coef. & -.113 & .032 & -.008 & .0591 & .145 & .002 & -.0003 \\
\hline Std Err & .014 & .006 & .005 & .011 & .004 & .001 & .00008 \\
\hline P-Value & .000 & .000 & .084 & .000 & .000 & .001 & .001 \\
\hline \multicolumn{8}{|l|}{$50 \%$} \\
\hline $\mathrm{R}^{2}=0.3481$ & Constant & $\mathrm{X} 1$ & $\mathrm{X} 2$ & $\mathrm{X} 3$ & $\mathrm{X} 4$ & X5 & X6 \\
\hline Coef. & -.084 & .0245 & -.0279 & .0819 & .190 & .009 & -.0004 \\
\hline Std Err & .009 & .0032 & .0031 & .0070 & .002 & .002 & .0001 \\
\hline P-Value & 0.000 & .000 & .000 & .000 & .000 & .000 & .000 \\
\hline \multicolumn{8}{|l|}{$75 \%$} \\
\hline $\mathrm{R}^{2}=0.3524$ & Constant & $\mathrm{X} 1$ & $\mathrm{X} 2$ & $\mathrm{X} 3$ & $\mathrm{X} 4$ & X5 & X6 \\
\hline Coef. & .0248 & .033 & -.066 & .084 & .222 & .014 & -.0005 \\
\hline Std Err & .0156 & .006 & .005 & .0143 & .004 & .0007 & .0001 \\
\hline P-Value & .112 & .000 & .000 & .000 & .000 & .000 & .000 \\
\hline
\end{tabular}

Table 5. The OLS method results for health

\begin{tabular}{llllllll}
\hline $\mathrm{R}^{2}=0.49$ & Constant & $\mathrm{X} 1$ & $\mathrm{X} 2$ & $\mathrm{X} 3$ & $\mathrm{X} 4$ & $\mathrm{X} 5$ & $\mathrm{X} 6$ \\
\hline Coef. & -.183 & .073 & -.018 & .028 & .265 & -.001 & -.000 \\
Std Err & .023 & .007 & .008 & .013 & .0065 & .002 & .000 \\
P-Value $^{*}$ & 0.000 & 0.000 & 0.020 & 0.039 & 0.000 & 0.732 & 0.831 \\
\hline
\end{tabular}

Note: Number of obs $=3716, \mathrm{~F}(7,3708)=516.27$, Root MSE $=.11926$, Prob $>\mathrm{F}=0.0000$.

Table 6 . The quantile regression results for health

\begin{tabular}{llllllll}
\hline $\mathbf{2 5 \%}$ & & & & & & \\
$\mathrm{R}^{2}=0.3972$ & Constant & $\mathrm{X} 1$ & $\mathrm{X} 2$ & $\mathrm{X} 3$ & $\mathrm{X} 4$ & $\mathrm{X} 5$ & $\mathrm{X} 6$ \\
\hline Coef. & -.266 & .046 & -.025 & .034 & .284 & .009 & -.000 \\
Std Err & .0105 & .003 & .003 & .006 & .002 & .000 & .000 \\
$\mathrm{P}-$ Value & 0.000 & 0.000 & 0.000 & 0.000 & 0.000 & 0.000 & 0.001 \\
\hline $\mathbf{5 0 \%}$ & & & & & & & \\
$\mathrm{R}^{2}=0.41$ & Constant & $\mathrm{X} 1$ & $\mathrm{X} 2$ & $\mathrm{X} 3$ & $\mathrm{X} 4$ & $\mathrm{X} 5$ & $\mathrm{X} 6$ \\
\hline Coef. & -.188 & .046 & -.025 & .034 & .284 & .008 & -.000 \\
Std Err & .010 & .003 & .003 & .006 & .002 & .001 & .0001 \\
$\mathrm{P}-$ Value & 0.000 & 0.000 & 0.000 & 0.000 & 0.000 & 0.008 & 0.000 \\
\hline $\mathbf{7 5 \%}$ & & & & & & & \\
$\mathrm{R}^{2}=0.39$ & Constant & $\mathrm{X} 1$ & $\mathrm{X} 2$ & $\mathrm{X} 3$ & $\mathrm{X} 4$ & $\mathrm{X} 5$ & $\mathrm{X} 6$ \\
\hline Coef. & -.077 & .038 & -.067 & .0499 & .308 & .026 & -.0002 \\
Std Err & .013 & .005 & .005 & .009 & .003 & .001 & .0001 \\
$\mathrm{P}-$ Value & 0.000 & 0.000 & 0.000 & 0.000 & 0.000 & 0.000 & 0.105 \\
\hline
\end{tabular}

Table 7. The OLS method results for transport

\begin{tabular}{llllllll}
\hline $\mathrm{R}^{2}=0.456$ & Constant & $\mathrm{X} 1$ & $\mathrm{X} 2$ & $\mathrm{X} 3$ & $\mathrm{X} 4$ & $\mathrm{X} 5$ & $\mathrm{X} 6$ \\
\hline Coef. & -.228 & .075 & -.041 & .001 & .398 & .031 & -.002 \\
Std Err & .036 & .007 & .012 & .022 & .008 & .003 & .0003 \\
P-Value & .000 & .000 & .001 & .951 & .000 & .000 & .000 \\
\hline
\end{tabular}

Note: Number of obs $=3526$, Root MSE $=.1868, \mathrm{~F}(7,3518)=421.15$, Prob $>\mathrm{F}=0.0000$. 
Table 8 . The quantile regression results for transport

\begin{tabular}{llllllll}
\hline $\mathbf{2 5 \%}$ & & & & & \\
$\mathrm{R}^{2}=0.327$ & Constant & $\mathrm{X} 1$ & $\mathrm{X} 2$ & $\mathrm{X} 4$ & $\mathrm{X} 4$ & $\mathrm{X} 5$ & $\mathrm{X} 6$ \\
\hline Coef. & -.388 & .080 & -001 & .063 & .372 & .007 & -.001 \\
Std Err & .022 & .006 & .008 & .012 & .006 & .002 & .0001 \\
$\mathrm{P}-$ Value & .000 & .000 & .856 & .000 & .000 & .000 & .000 \\
\hline $\mathbf{5 0 \%}$ & & & & & & \\
$\mathrm{R}^{2}=0.360$ & Constant & $\mathrm{X} 1$ & $\mathrm{X} 3$ & $\mathrm{X} 4$ & $\mathrm{X} 5$ & $\mathrm{X} 6$ & $\mathrm{X} 6$ \\
\hline Coef. & -.326 & .104 & -.042 & .096 & .452 & .031 & -.001 \\
Std Err & .022 & .004 & .008 & .0128 & .005 & .002 & .0002 \\
$\mathrm{P}-$ Value & .000 & .000 & .000 & .000 & .000 & .000 & .000 \\
\hline $\mathbf{7 5 \%}$ & & & & & & & \\
$\mathrm{R}^{2}=0.355$ & Constant & $\mathrm{X} 1$ & $\mathrm{X} 2$ & $\mathrm{X} 3$ & $\mathrm{X} 4$ & $\mathrm{X} 5$ & $\mathrm{X} 6$ \\
\hline Coef. & -.210 & .116 & -.090 & .089 & .509 & .066 & -.001 \\
Std Err & .040 & .007 & .014 & .028 & .009 & .003 & .0003 \\
$\mathrm{P}-$ Value & .000 & .000 & .000 & .000 & .000 & .000 & .001 \\
\hline
\end{tabular}

Table 9. The OLS method results for metal

\begin{tabular}{llllllll}
\hline $\mathrm{R}^{2}=0.428$ & Constant & $\mathrm{X} 1$ & $\mathrm{X} 2$ & $\mathrm{X} 3$ & $\mathrm{X} 4$ & $\mathrm{X} 5$ & $\mathrm{X} 6$ \\
\hline Coef. & -.241 & .023 & -.022 & .128 & .231 & .054 & -.0003 \\
Std Err & .040 & .004 & .014 & .023 & .008 & .003 & .0003 \\
P-Value & .000 & .000 & .114 & .000 & .000 & .000 & .244 \\
\hline
\end{tabular}

Note: Number of obs $=2210$, Root MSE $=.16423, \mathrm{~F}(7,2202)=235.24$.

Table 10. The quantile regression results for metal

\begin{tabular}{llllllll}
\hline $\mathbf{2 5 \%}$ & & & & & \\
$\mathrm{R}^{2}=0.330$ & Constant & $\mathrm{X} 1$ & $\mathrm{X} 2$ & $\mathrm{X} 3$ & $\mathrm{X} 4$ & $\mathrm{X} 5$ & $\mathrm{X} 6$ \\
\hline Coef. & -.207 & .038 & .001 & .137 & .185 & .005 & -.0003 \\
Std Err & .0254 & .003 & .009 & .013 & .006 & .002 & .0001 \\
$\mathrm{P}-$ Value & .000 & .000 & .937 & .000 & .000 & .009 & .061 \\
\hline $\mathbf{5 0 \%}$ & & & & & & \\
$\mathrm{R}^{2}=0.375$ & Constant & $\mathrm{X} 1$ & $\mathrm{X} 2$ & $\mathrm{X} 3$ & $\mathrm{X} 4$ & $\mathrm{X} 5$ & $\mathrm{X} 6$ \\
\hline Coef. & -.152 & .045 & -.034 & .121 & .242 & .025 & -.0003 \\
Std Err & .018 & .002 & .006 & .011 & .003 & .001 & .0002 \\
$\mathrm{P}-$ Value & .000 & .000 & .000 & .000 & .000 & .000 & .061 \\
\hline $\mathbf{7 5 \%}$ & & & & & & & \\
$\mathrm{R} 2=0.401$ & Constant & $\mathrm{X} 1$ & $\mathrm{X} 2$ & $\mathrm{X} 3$ & $\mathrm{X} 4$ & $\mathrm{X} 5$ & $\mathrm{X} 6$ \\
\hline Coef. & -.102 & .060 & -.060 & .112 & .281 & .047 & -.0003 \\
Std Err & .024 & .002 & .009 & .015 & .004 & .002 & .0002 \\
P-Value & .000 & .000 & .000 & .000 & .000 & .000 & .097 \\
\hline
\end{tabular}

\section{Summary and Conclusion}

The specific aim of this study is to identify the relationship between micro firm profitability and factors such as growth sales, firm size, lagged profitability, productivity, asset turnover and age, by using data for more than 2,500 Swedish micro firms for the year 2007.

The main purpose is to provide additional empirical evidence by measuring the profitability of four important Swedish micro firm sectors. In order to understand how firms' profitability relates to key variables such as growth sales, firm size, lagged profitability, productivity, asset turnover and firm age, the OLS and the quantile regression techniques are used to estimate the profitability for these firms.

The results show that lagged profitability, productivity growth sales and asset turnover have significant positive effects on micro firms' profitability. Meanwhile, the firms' size and age have negative effects on the dependent variable. 
In general, the results indicate some statistically significant negative effect of firm size on profitability. Meanwhile, the metal firm size; in this case in the 75th percentile, has demonstrated a negative significant effect, while firm size has shown a non-significant and also negative effect in the case of OLS. On the other hand, looking at the results for the 25th percentile regression, regarding the firm size variable, one finds a more differentiated picture than in the cases of the 50th and 75th percentiles. The results here would suggest that for this low percentile the effect seems to be even smaller, and has a negative sign and is non-significant, which is different from what is suggested by the 50th and 75th percentile regression. Again, such information cannot be found from the OLS regression.

Using both estimation methods, we found the variables growth sales, lagged profitability, productivity and asset turnover to have positive and significant effects on the profitability of the different micro firms, while the variable of firm size has negative and significant effects on profitability for all the micro firms in this study. The OLS and quantile regression results in all cases showed that the firm age variable has a negative sign and is non-significant for all micro firms in our study.

The magnitude of the parameters, however, varies for the different firms and estimation methods. Other variables have occasionally shown significant effects, depending on the estimation method, or which part of the profitability distribution we are estimating. In general, we found the quantile regression approach to be very useful in providing more detailed results than the usual OLS. The quantile regression approach also helps in understanding better the dynamics of the factors that may affect the profitability of the micro firms. Moreover, the correlation estimation, shows a weak correlation between the determinants of the micro firms' profitability such as age, and asset turnover. On the other hand, we found a strong correlation between productivity and firms' profitability. We also found that productivity has a greater correlation with the profitability variable.

To sum up, the results confirm the hypothesis that the included key factors are, in fact, important predictors of micro firm profitability. This research has also helped to disentangle the theoretical problems mentioned at the beginning of this article that are associated with key factors in the study. Some previous studies, which have studied the effect of growth, suggested that the growth factor cannot affect companies' profitability significantly. Based on a sample of Swedish micro firms, this article contributes to the literature showing evidence of a positive and statistically significant relationship between growth and profitability. Therefore, we can conclude that the employees' effect, as a consequence of the possibility for greater profitability.

The finding of this study concerning the impact of microeconomic suggestions such as competition, comparative advantage of production and technological progress and the law of diminishing returns on profitability of micro firm Swedish companies by using cross-section data for more 3000 micro firms, confirms a relationship between the profitability and economic activities - they are more likely to be profitable through steady time. Furthermore, the findings provide evidence about effects of the total factor productivity (comparative advantage) and the quantity sales during Sweden's transition to a steady state. One possible interpretation can be that government policy arrangements would affect business profitability differently in the short and the long term. In addition, the short-term policies (i.e., demand side policies) are likely to have less influence than policies aimed at supporting to moderate labour and fixed costs payments.

\subsection{Implications}

Previous studies have used descriptive statistics methods, the generalised method of moment (GMM) and ordinary least squares (OLS) techniques to analyse the profitability of small firms. In this study, we apply OLS and quantile regression techniques. Combining these methods has enabled us to overcome difficulties such as highly skewed data and outliers. We have also been able to make more subtle inferences about the effects of key factors such as growth in sales, productivity, firm size and asset turnover on profitability. The wider implication for micro firm researchers and for firm researchers in general, is that it might be possible to overcome difficulties caused by non-normally distributed data, and to draw more subtle inferences by using proper estimation methodologies, which complement each other.

The size in terms of the number of employees has a negative impact on micro firm's profitability, and changing size is associated with worsening profitability. Our concluding recommendation, to those who are responsible for profitability recruitment, can be stated in the following two points:

1. Do not increase the number of employees, especially if you have able employees;

2. Encourage the growth of sales of Swedish micro firms, by using more advertising activities and innovations.

\section{Acknowledgement}

The authors would like to thank professor Ghazi Shukur for Valuable suggestions. 


\section{References}

Barney, J. (2001). Resources-based theories of competitive advantage: A ten-year retrospective on the resource based view. Journal of Management, 27(6), 643-650. http://dx.doi.org/10.1177/014920630102700602

Buchinsky, M. (1998). Recent advances in quantile regression models: A practical guide for empirical research. Journal of Human Resources, 33(1), 88-126. http://dx.doi.org/10.2307/146316

Coad, A., \& Rao, R. (2008). Innovation and firm growth in high-tech sectors: A quantile regression approach. Research Policy, 37(4), 633-648. http://dx.doi.org/10.1016/j.respol.2008.01.003

Coed, A., \& HölzI, W. (2009). On the autocorrelation of growth rates, evidence for micro, small and large firms from the Austrian service industries, 1975-2004. J Ind Compet Trade, 9, 139-166.

Demsetz, H. (1973). Industry structure, market rivalry, and public policy. Journal of Law and Economics, 16(1), 1-9. http://dx.doi.org/10.1086/466752

Dilling-Hansen, M. (2005). Small firms' performance and ownership structure. Working paper, School of Economics and Management, University of Aarhus, Denmark.

Europstat. (1994). Enterprises in the European Community. Third report, Luxembourg.

Evans, D. S. (1987). Tests of alternative theories of firm growth. Journal of industrial Economics, 35(4), 567-581. http://dx.doi.org/10.2307/2098588

Fotopoulos, G., \& Louri, H. (2004). Firm growth and FDI: Are multinationals stimulating local industrial development? Journal of Industry, Completion and Trade, 4, 163-189. http://dx.doi.org/10.1023/B:JICT.0000047300.88236.f1

Geroski, P., \& Jaquemin, A. (1998). The persistence of profits: A European comparison. Economic Journal, 98, 375-389. http://dx.doi.org/10.2307/2233373

Glancey, K. (1998). Determinanants of growth and profiotability in small entrepreneurial firms. International Journal of Entrepreneurial Behaviour \& Research, 4(1), 18-27. http://dx.doi.org/10.1108/13552559810203948

Goddard, J., Tavakoli, M., \& Wilson, J. (2005). Determinants of profitability in European manufacturing and services: Evidence from a dynamic panel data. Applied Financial Economics, 15(18), 1269-1282. http://dx.doi.org/10.1080/09603100500387139

Greiner, L. (1972). Evolution and revolutions as organisations grow. Harvard Business Review, 50(4), 37-46.

Gschwandtner, A. (2005). Profit persistence in the very long run: Evidence from survivor and exciters. Applied Economics, 37(7), 793-806. http://dx.doi.org/10.1080/0003684042000337406

Hardwick, P. (1997). Measuring cost inefficiency in the UK life insurance industry. Applied Financial Economics, 7(1), 37-44. http://dx.doi.org/10.1080/096031097333835

Harhoff, D., Stahl, K., \& Woywode, M. (1998). Legal form, growth and exit of west Germany firms-empirical results for manufacturing, Construction, trade and service industries. Journal of Industrial Economics, 46(4), 453-488. http://dx.doi.org/10.1111/1467-6451.00083

Hawawini, G., Subramanian, V., \& Verdin, P. (2003). Is performance driven by industry or firm specific factors? New look at the evidence. Strategic Management Journal, 24(1), 1-16. http://dx.doi.org/10.1002/smj.278

Jensen, M., \& Murphy, K. (1990). Performance pay and top-management incentives. Journal of Political Economy, 98(2), 225-264. http://dx.doi.org/10.1086/261677

Johnson, P., Conway, C., \& Kattuman, P. (1999). Small business growth in the short run. Small Business Economics, 12(2), 103-112. http://dx.doi.org/10.1023/A:1008006516084

Jovanovic, B. (1982). Selection and evaluation of industry. Econometrica, 50, 649-488. http://dx.doi.org/10.2307/1912606

Koenker, R. (2005). Quantile regression, Econometrics Society Monographs. Cambridge University Press.

Koenker, R., \& Bassett, G. (1978). Regression quantiles. Econometrica, 46(1), 33-50. http://dx.doi.org/10.2307/1913643

Mueller, D. (1986). Profits in the Long-Run. Cambridge: Cambridge University Press. http://dx.doi.org/10.1017/CBO9780511664731 
Newbold, P. (2003). Statistics for Business and Economics (5th ed.). USA, New Jersey: Prentice Hall.

Pi, L., \& Timme, S. (1993). Corporate control and bank efficiency. Journal of Banking and Finance, 17(2-3), 515-530. http://dx.doi.org/10.1016/0378-4266(93)90050-N

Pushner, G. (1995). Equity ownership structure, leverage and profitability: Empirical evidence from Japan. Pacific Basin Finance Journal, 3(2-3), 241-255. http://dx.doi.org/10.1016/0927-538X(95)00003-4

Reichstein, T., Dahl, M. S., Ebersberger, B., \& Jensen, M. B. (2009). The devil dwells in the tails: A quantile regression approach to firm growth. Journal of Evolutionary Economics, 20(2), 219-231. http://dx.doi.org/10.1007/s00191-009-0152-x

Schumacher, S., \& Boland, M. (2005). The persistence of profitability among firms in the food economy. American Journal of Agriculture Economics, 30(2), 173-199.

Slater, S., \& Olson, E. (2002). A fresh look at industry and market analysis. Business Horizons, 45(1) (SP. Suppl), $15-22$.

Stulz, R. (1990). Managerial discretion and optimal financing policies. Journal of Financial Economics, 26(1), 3-27. http://dx.doi.org/10.1016/0304-405X(90)90011-N

Swedish Statistical central Office (SCB). (2007 and 2009). Statistical Yearbook of Sweden. Statistics Sweden.

Thurik, A. R. (2004). Entrepreneurship, Economic Growth and the Shift from the Managed to the Entrepreneurial Economy. In Hallin, G och Östhol A (red), På den tillväxtpolitiska agendan, ITPS-Rapport, A2004:023, Östersund, Sweden.

Winter, R. (1994). The dynamic of competitive insurance market. Journal of Financial Intermediation, 3(4), 379-415. http://dx.doi.org/10.1006/jfin.1994.1011

Wyn, J. (1998). The fourth wave. Best's Review, 99(1), 53-57.

\section{Notes}

Note 1. The number of employees in the micro firms represented $18 \%$ of the Swedish workforce in 2007. The contribution of micro firms in Swedish GDP was around 18\% (SCB, 2007). Swedish national statistics indicated that $90 \%$ of Swedish firms are defined as micro firms, SCB, (2009).

Note 2. In 1979, in the UK, Margaret Thatcher's Cabinet began to promote the birth of new firms through the Allowance Schema enterprise. In the US, during the Carter Administration in the late 1970s, the policies for small business were strengthened, based on the concept of birthright economy. Since the end of the 1970s, in Sweden, smaller, and especially micro companies, began to receive support from the Government to play a role in the economy (Thurik, 2004).

Note 3. Buchinsky (1998); "when the error term is non-normal, Quantile regression estimators may more efficient than least squares estimators.", for more on quantile regression see also Koenker 2005. 